\title{
Infeksi Heterodoxus spiniger pada Canis lupus familiaris
}

\author{
Tri Ayu Kristianty*, Zulfa Ichsanniyati, Sukmasari Arifah \\ Klinik Hewan My Vets Bumi Serpong Damai, Tangerang Selatan, Banten
}

ABSTRAK: Seekor anjing domestik (Canis lupus familiaris) liar didiagnosa terinfeksi kutu pengunyah Heterodoxus spiniger di Klinik hewan My Vets Bumi Serpong Damai. Heterodoxus spiniger merupakan kutu pengunyah yang menginfeksi anjing domestik (Canis lupus familiaris), ras anjing lain, dan hewan marsupialia. Kutu ini juga merupakan inang antara dari cacing pita Dipylidium caninum dan filaria cacing gilig Dipetalonema reconditum. Studi kasus ini akan membahas tentang tata cara pendiagnosaan dan penanganan terhadap infeksi Heterodoxus spiniger pada Canis lupus familiaris. Diagnosa dilakukan melalui pemeriksaan fisik dan penegakan diagnosa dengan pemeriksaan mikroskopis teknik trichogram pada contoh kutu. Pengobatan terhadap kutu ini dilakukan menggunakan kombinasi flumethryn dan ivermectin efektif hingga 7 hari.

Kata kunci:

Heterodoxus spiniger, Canis lupus familiaris

\section{- PENDAHULUAN}

Heterodoxus spiniger merupakan kutu pengunyah yang masuk ke dalam kelas Insecta, ordo Phthiraptera, subordo Amblycera, dan famili Boopidae. Heterodoxus sp. memiliki tubuh yang panjang, kepala membulat di bagian anterior, palpus maxillaris dan antena di lengkungan lateral sisi kepala, segmentasi abdomen tertutupi oleh rambut kecil yang dinamakan setae, serta dua kuku di masing-masing pretarsus (Robert \& Janovy, 2000).

Heterodoxus spiniger termasuk ke dalam spesies haematophagous mallophaga atau serangga yang memperoleh makanan dari darah inang. Dikarenakan cara mendapatkan makanannya dari darah, Heterodoxus sp. tidak hanya mempengaruhi kebugaran dan pertumbuhan inang tetapi juga menjadi inang antara dari cacing pita Dipylidium caninum dan filaria cacing gilig Dipetalonema reconditum (Agarwal et al., 1982). Heterodoxus spiniger menginfeksi kulit anjing domestik (Canis lupus familiaris), ras anjing lain, dan hewan marsupialia umumnya di dorsal tubuh bagian posterior. Heterodoxus sp. banyak ditemukan pada ujung proksimal batang rambut dekat kulit (Robert \& Janovy, 2000). Studi kasus ini akan membahas tentang tata cara pendiagnosaan dan penanganan infeksi Heterodoxus spiniger pada Canis lupus familiaris

\section{- KASUS}

Anamnesa dan signalement: Seekor anjing domestik (Canis lupus familiaris) betina datang ke Klinik Hewan My Vets Bumi Serpong Damai, Tangerang Selatan dari Bahorok, Sumatera Utara. Anjing merupakan anjing liar dengan latar belakang yang tidak diketahui. Anjing ditemukan dengan kondisi malnutrisi, lumpuh pada kedua kaki belakang, dan terinfeksi banyak kutu (Gambar 1).
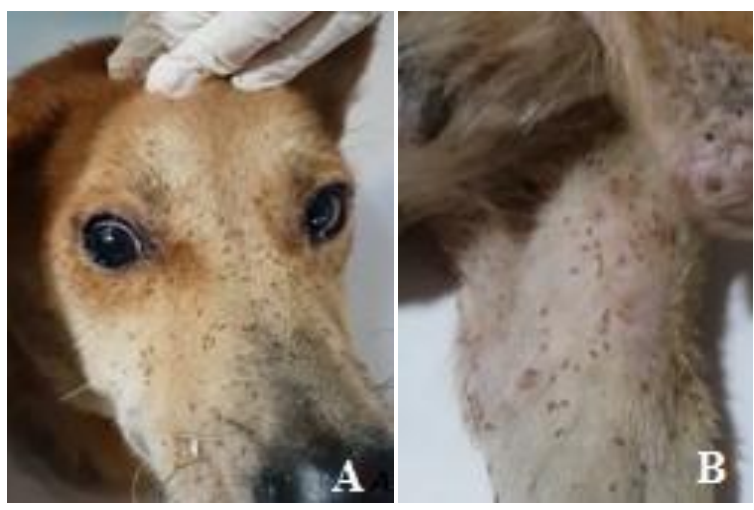

Gambar 1 Manifestasi parasit Heterodoxus spiniger pada kulit anjing domestik (a) daerah muka dan (b) daerah ekstremitas caudalis bagian medial

Pemeriksaan fisik dan pemeriksaan mikroskopis: Anjing memiliki berat badan $11,6 \mathrm{~kg}$ dan suhu tubuh $38,9^{\circ} \mathrm{C}$. Pemeriksaan fisik ditemukan banyak kutu pengunyah Heterodoxus sp. pada daerah kulit dan folikel rambut di seluruh bagian tubuh anjing. Lesio kulit yang terlihat adalah erythema dan kerak di seluruh tubuh dan erosi di kedua lutut, phalanx ke 3 dan 4 kaki kanan belakang, serta phalanx ke 2 kaki kiri belakang. Hasil pemeriksaan mikroskopik dengan teknik trichogram memperlihatkan adanya kutu dewasa dan telur Heterodoxus sp. (Gambar 2).

Diagnosa: Hewan didiagnosa terinfeksi oleh Heterodoxus spiniger berdasarkan pemeriksaan fisik dan mikroskopis.

Prognosa: Manifestasi Heterodoxus spiniger bersifat fausta dan dapat dihilangkan dengan insektisida.

Diterima: 19-09-2018 | Direvisi: 15-10-2018 | Disetujui: 22-10-2018

(C) 2018 CC-BY-SA. Ini adalah artikel Open Access yang didistribusikan berdasarkan ketentuan dari Creative Commons Attribution ShareAlike 4.0 International License (https://creativecommons.org/licenses/by-sa/4.0/). 

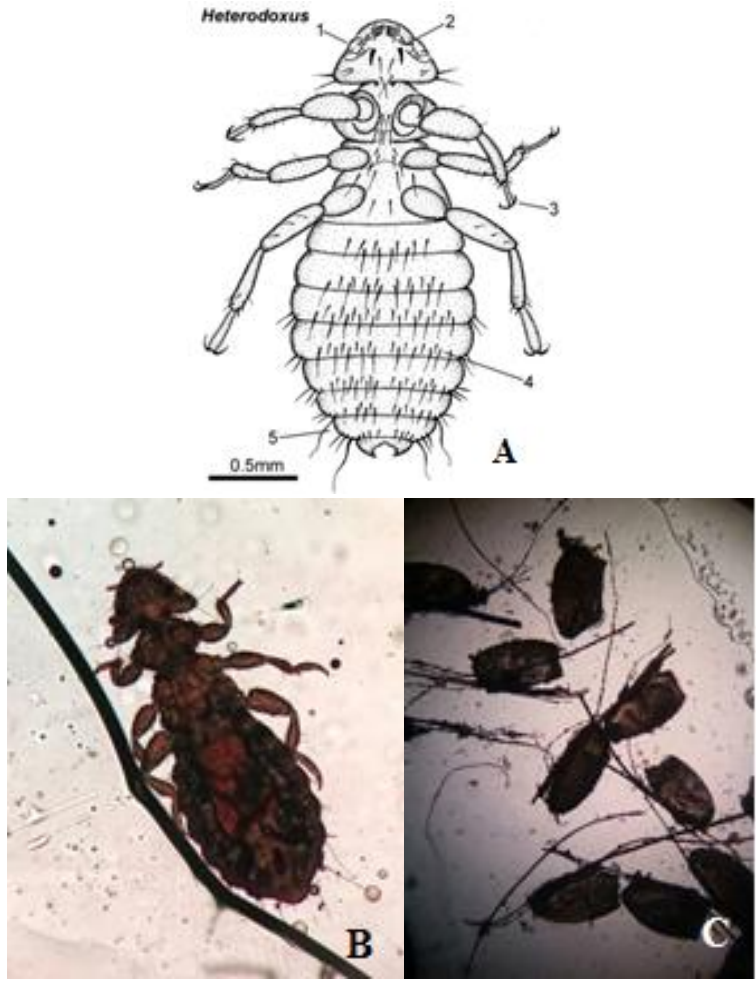

Gambar 2 A) Ventral anatomi Heterodoxus sp. betina, B) Mikroskopis Heterodoxus spiniger dewasa dan C) Telur.

Keterangan 2A: 1. Kepala, posisi anterior membulat; 2. Palpus, ukuran kecil terletak di anterior antena; 3 . Kaki, pada bagian ujung terdapat sepasang kuku; 4. Segmentasi abdomen, memiliki setae

yang tersusun; 5. Abdomen membulat di daerah posterior.

Terapi dan Penanganan: Terapi pertama untuk manifestasi Heterodoxus sp dilakukan dengan pemberian flumethrin $6 \%$ (Bayticol@-Bayer) secara topikal ke seluruh tubuh anjing yang dilanjutkan dengan pemberian injeksi ivermectin (200 $\mu \mathrm{g} / \mathrm{kg} \mathrm{BB}$ ) secara subkutan serta pencukuran seluruh rambut anjing tersebut. Mandi dengan shampo mengandung chlorhexidine dilakukan untuk membersihkan sisa-sisa telur kutu yang ada di rambut serta mengurangi infeksi sekunder bakteri pada kulit. Terapi ini dilakukan pada hari ke-3 saat kondisi hewan telah stabil. Hewan disisir dengan sisir bergigi rapat untuk membantu membuang telur kutu yang masih menempel di sisa rambut.

\section{- HASIL DAN PEMBAHASAN}

Anjing diberikan penanganan dengan penyemprotan flumethrin $6 \%$ pada tubuh, penyuntikan ivermectin injeksi, pencukuran rambut dan dilanjutkan mandi dengan shampo chlorhexidine. Flumethrin merupakan sintesis pyrethroid yang memiliki cara kerja seperti organochlorin. Flumethrin bekerja di membran sel syaraf dengan cara menghambat penutupan gerbang ion sodium selama repolarisasi, hal ini menyebabkan paralisa dan kematian. Ivermectin merupakan agen antiparasit semisynthetic macrocylic lactone yang juga berikatan dengan gamma-aminobutyric acid (GABA) gated chloride channel (Currie \& McCarthy, 2010). Hasil pengobatan menunjukkan terjadi pengurangan populasi kutu pengunyah dewasa sebanyak $100 \%$ dan telur kutu sebanyak $30 \%$ pada hari pertama. Populasi telur kutu $100 \%$ hilang setelah terapi mandi dan penyisiran rutin dengan sisir bergigi rapat selama 1 minggu (Gambar 3). Efikasi kombinasi flumethrin dan ivermectin mendekati produk antiparasit Selamectin yang sering dipakai dipasaran. Selamectin membunuh $100 \%$ populasi Trichodectes canis pada anjing dan $100 \%$ populasi Felicola subrostratus pada kucing setelah pengaplikasian obat (Shanks et al., 2003)

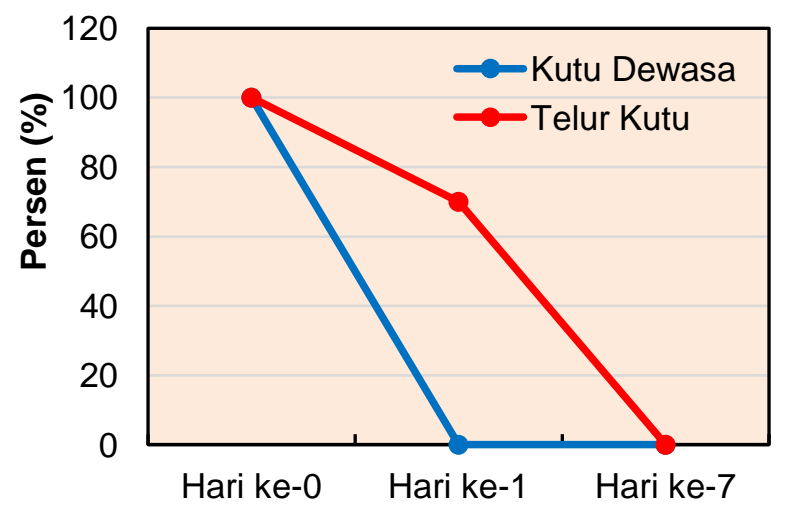

Gambar 3 Perubahan presentasi populasi Heterodoxus spiniger sebelum dan setelah pengobatan.

\section{- SIMPULAN}

Heterodoxus spiniger merupakan haemotophagous mallophaga yang menginfeksi kulit anjing domestik. Penyemprotan flumetrin dan penyuntikan ivermectin efektif untuk menghilangkan populasi kutu pengunyah tersebut.

\section{- INFORMASI PENULIS}

Penulis untuk Korespondensi

*TAK: felix_ayu@yahoo.com

Klinik Hewan My Vets Bumi Serpong Damai, Tangerang Selatan, Banten

\section{- PUSTAKA ACUAN}

Agarwal GP, Chandra S, Saxena AK. 1982. Feeding habits of dog louse Heterodoxus spiniger (End.) (Mallophaga, Amblycera). Zeitschrift für Angewandte Entomologie, 94(1-5): 134-137.

Currie BJ, McCarthy JS. 2010. Permethrin and ivermectin for scabies. New England Journal of Medicine, 362(8): 717-725.

Roberts L, Janovy J. 2000. Foundation of parasitology, 5th. WCB Company, UK, 347-410.

Shanks DJ, Gautier P, McTier TL, Evans NA, Pengo G, Rowan TG. 2003. Efficacy of selamectin against biting lice on dogs and cats. Veterinary Record, 152(8): 234-237. 